\title{
Corona and Our Role
}

\section{Suman Baral*}

Department of Surgery, Lumbini Medical College and Teaching Hospital ltd, Nepal

*Corresponding Author: Suman Baral, Department of Surgery, Lumbini Medical

College and Teaching Hospital ltd, Nepal.
Received: March 10, 2020

Published: March 30, 2020

(C) All rights are reserved by Suman Baral.
It has almost been more than two months when the first case of novel corona virus officially named as COVID 19 was found in Wuhan, China. It has already spread to 100 countries as of $9^{\text {th }}$ of March and the trends are increasing despite of the precautionary measures being taken [1]. Many of the countries have seen a greater strain in the health system owing to increased number of patients with this viral infection and if this scenario continues, this definitely will have negative impact on health care delivery due to unavailability of intensive care units, medications and logistics necessary for treating individuals. The epidemic nature of the virus which has been gradually progressing for pandemicity is being dealt with utmost caution in every country with proper isolation of known or proven cases whilst quarantine of the suspected individuals which itself is a major challenge. We, as health personnel who is on the frontline have an important responsibility of treating the infected ones with utmost caution without contracting oneself owing to infectious nature of the virus. This is even disheartening to see the front liners losing lives as exemplified by the Chinese physicians [2]. The commencing phase of such disasters could be confused however, the job as a physician or a health personnel is to try to oversee the preparation and planning of the institution and community on how to handle the local outbreaks, sorting out the capacities of the available facilities, determining the hierarchy of the commandment, accretion and allocation of the resources along with development of the reliable correspondence systems. Our daily jobs, working as a physician has put us at an extra risk, while on being vigilant, the willingness to accept that risk, help the needy ones and expressing compassion is what makes us a professional. Current scenario now being termed as 'a dooms day' or a 'viral armageddon' by media which ought to be discouraged and the proper role that they should play ought to be explaining the preventive measures, washing hands with soap water or alcohol-based preparations and preventing gatherings. Experiences till date had led to know that there are more than $95 \%$ chances of recovery from the disease and fatality rate increases as the age increases and, in those patients, who have underlying comorbidities like heart disease, diabetes and compromised immunity [3]. Complications like pneumonia and Acute Respiratory Distress Syndrome has been the most important triggers for mortality and various studies have been on- going for the development of vaccines which might delay the progression of spread of the disease, which we expect will be sooner on its way. This is the peak moment to be conversant of the proper ways to wear and junking of personal protection equipment's along with their bona fide indications, usage and availability [4]. Much like our predecessors faced in the history, yet here is the another one and we hope to see the same sort of dedication among our fellow medicos. The end point is: 'Stay Safe, Be Prepared, Get Ready'. From surgeon's perspective, being savvied in disaster preparation and getting ready for this new challenge should be right down our lane. Reminiscing the childhood memories, I still remember my mother insisting to wash hands and I believe that's what we ought to pass on to our patients. Together, lets fight this evil. Together, WE CAN!.

\section{Bibliography}

1. "Coronavirus latest: scientific conferences cancelled worldwide". Nature (2020).

2. "Several young doctors in China have died of the coronavirus. Medical workers are far more vulnerable to infection than the general population" (2020).

3. "People at Risk for Serious Illness from COVID-19".

4. "Coronavirus disease (COVID-19) advice for the public: When and how to use masks".

\section{Assets from publication with us}

- Prompt Acknowledgement after receiving the article

- Thorough Double blinded peer review

- Rapid Publication

- Issue of Publication Certificate

- High visibility of your Published work

Website: www.actascientific.com

Submit Article: www.actascientific.com/submission.php

Email us: editor@actascientific.com

Contact us: +919182824667 